University of Nebraska - Lincoln

DigitalCommons@University of Nebraska - Lincoln

Faculty Publications from the Harold W. Manter Laboratory of Parasitology

6-1990

\title{
Coccidia (Apicomplexa) from Heteromyid Rodents in the Southwestern United States, Baja California, and Northern Mexico with Three New Species from Chaetodipus hispidus
}

\author{
Paulette L. Ford \\ Rocky Mountain Research Station, Albuquerque Lab, plford@fs.fed.us \\ Donald W. Duszynski \\ University of New Mexico, eimeria@unm.edu \\ C. T. McAllister \\ University of North Texas
}

Follow this and additional works at: https://digitalcommons.unl.edu/parasitologyfacpubs

Part of the Parasitology Commons

Ford, Paulette L.; Duszynski, Donald W.; and McAllister, C. T., "Coccidia (Apicomplexa) from Heteromyid Rodents in the Southwestern United States, Baja California, and Northern Mexico with Three New Species from Chaetodipus hispidus" (1990). Faculty Publications from the Harold W. Manter Laboratory of Parasitology. 159.

https://digitalcommons.unl.edu/parasitologyfacpubs/159

This Article is brought to you for free and open access by the Parasitology, Harold W. Manter Laboratory of at DigitalCommons@University of Nebraska - Lincoln. It has been accepted for inclusion in Faculty Publications from the Harold W. Manter Laboratory of Parasitology by an authorized administrator of DigitalCommons@University of Nebraska - Lincoln. 


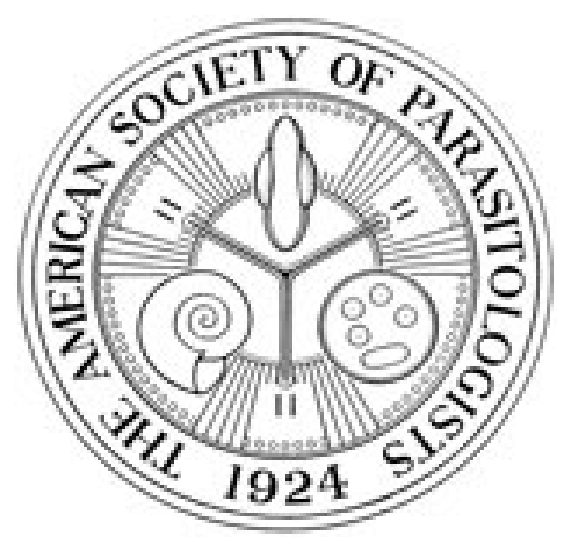

Coccidia (Apicomplexa) from Heteromyid Rodents in the Southwestern United States, Baja California, and Northern Mexico with Three New Species from Chaetodipus hispidus Author(s): P. L. Ford, D. W. Duszynski, C. T. McAllister

Source: The Journal of Parasitology, Vol. 76, No. 3 (Jun., 1990), pp. 325-331

Published by: The American Society of Parasitologists

Stable URL: http://www.jstor.org/stable/3282659

Accessed: $21 / 04 / 2010$ 00:19

Your use of the JSTOR archive indicates your acceptance of JSTOR's Terms and Conditions of Use, available at http://www.jstor.org/page/info/about/policies/terms.jsp. JSTOR's Terms and Conditions of Use provides, in part, that unless you have obtained prior permission, you may not download an entire issue of a journal or multiple copies of articles, and you may use content in the JSTOR archive only for your personal, non-commercial use.

Please contact the publisher regarding any further use of this work. Publisher contact information may be obtained at http://www.jstor.org/action/showPublisher?publisherCode=asp.

Each copy of any part of a JSTOR transmission must contain the same copyright notice that appears on the screen or printed page of such transmission.

JSTOR is a not-for-profit service that helps scholars, researchers, and students discover, use, and build upon a wide range of content in a trusted digital archive. We use information technology and tools to increase productivity and facilitate new forms of scholarship. For more information about JSTOR, please contact support@ jstor.org.

The American Society of Parasitologists is collaborating with JSTOR to digitize, preserve and extend access to The Journal of Parasitology. 


\title{
COCCIDIA (APICOMPLEXA) FROM HETEROMYID RODENTS IN THE SOUTHWESTERN UNITED STATES, BAJA CALIFORNIA, AND NORTHERN MEXICO WITH THREE NEW SPECIES FROM CHAETODIPUS HISPIDUS
}

\author{
P. L. Ford, D. W. Duszynski, and C. T. McAllister* \\ Department of Biology, The University of New Mexico, Albuquerque, New Mexico 87131
}

ABSTRACT: Fecal samples from 223 heteromyid rodents of 4 genera and 13 species were collected from California, New Mexico, and Texas and from Baja California Norte and Sonora, Mexico. Of these, 84 (38\%) were infected with coccidian oocysts; 72 of $84(86 \%)$ infected animals had only 1 species of coccidian. Eleven species of coccidia were identified including 1 cyclosporan and 10 eimerians; the cyclosporan and 2 of the eimerians are described as new species. Sporulated oocysts of Cyclospora angimurinensis $\mathbf{n}$. sp. were subspheroidal, $21.9 \times$ $19.3(19-24 \times 16-22) \mu \mathrm{m}$, with sporocysts lemon-shaped, $11.9 \times 9.5(9-15 \times 8-11) \mu \mathrm{m}$; it was found in 1 of 20 (4\%) Chaetodipus hispidus. Sporulated oocysts of Eimeria chaetodipi $\mathrm{n}$. sp. were subspheroidal, $16.7 \times 14.6$ (13-19.5 × 12-17) $\mu \mathrm{m}$, with sporocysts ovoidal, $8.7 \times 6.6(7.5-10.5 \times 5-7.5) \mu \mathrm{m}$; it was found in 3 of $20(15 \%)$ C. hispidus. Sporulated oocysts of Eimeria hispidensis n. sp. were subspheroidal, $20.5 \times 17.4(17-23 \times 14-21)$ $\mu \mathrm{m}$, with sporocysts lemon-shaped, $9.3 \times 7.2(7.5-10.5 \times 5-9) \mu \mathrm{m}$; it was found in 4 of $20(20 \%) C$. hispidus. Prevalence of infection included 0 of 20 Chaetodipus arenarius, 0 of 16 Chaetodipus baileyi, 25 of 46 (54\%) Chaetodipus californicus, 13 of 30 (43\%) Chaetodipus fallax, 7 of 20 (35\%) Chaetodipus formosus, 14 of 20 (70\%) C. hispidus, 4 of 25 (16\%) Chaetodipus penicillatus, 5 of 7 (71\%) Chaetodipus spinatus, 8 of 21 (38\%) Dipodomys elator, 1 of 1 Perognathus flavescens, 5 of 11 (45\%) Perognathus flavus, 0 of 3 Perognathus inornatus, and 2 of $3(67 \%)$ Liomys pictus. The following coccidians were identified from infected rodents: $C$. angimurinensis n. sp. from $C$. hispidus; Eimeria albigulae from C. californicus; Eimeria arizonensis from $C$. californicus and $D$. elator; E. chaetodipi n. sp. from C. hispidus; Eimeria balphae from D. elator; $E$. hispidensis n. $\mathbf{s p}$. from $C$. hispidus; Eimeria langebarteli from C. hispidus; Eimeria liomysis from L. pictus; Eimeria merriami from $C$. penicillatus; Eimeria reedi from $C$. californicus, $C$. fallax, $C$. formosus, $C$. hispidus, $C$. penicillatus, $C$. spinatus, and P. flavus; and Eimeria scholtysecki from C. californicus.

In our continuing effort to compile information on coccidian infections in natural populations of wild mammals, we sampled 3 genera of pocket mice, Chaetodipus, Liomys, and Perognathus spp., and the Texas kangaroo rat, Dipodomys elator, from a variety of localities in California, New Mexico, and Texas and in Baja California Norte and Sonora, Mexico. This paper summarizes our work and reports 3 new species of coccidia, 1 cyclosporan, and 2 eimerians.

\section{MATERIALS AND METHODS}

Mice were live-trapped and fecal samples were collected from them and stored in $2 \%(\mathrm{w} / \mathrm{v})$ aqueous potassium dichromate $\left(\mathrm{K}_{2} \mathrm{Cr}_{2} \mathrm{O}_{7}\right)$. Methods used for storage and processing fecal samples and for concentrating, measuring, and photographing oocysts have been described in detail (Duszynski et al., 1982; Stout and Duszynski, 1983). Measurements are given in micrometers $(\mu \mathrm{m})$ with size ranges in parentheses following the means. Oocysts were measured and photographed when they were between 83 (new species) and 3,168 (pre-

Received 20 October 1989; revised 18 January 1990; accepted 18 January 1990.

* Department of Biological Sciences, University of North Texas, Denton, Texas 76203. viously described species) days old. Skeletons, skins, and tissues for electrophoresis for most hosts are deposited in the Museum of Southwestern Biology (MSB), The University of New Mexico (UNM). Mice collected in Hardeman, Hood, Jack, Johnson, and Somervell counties, Texas, are deposited in the Arkansas State University Museum of Zoology (ASUMZ). Syntypes (=phototypes, see Bandoni and Duszynski, 1988) of sporulated oocysts of our 3 new species have been deposited in the U.S. National Museum Parasite Collection (USNMPC), Beltsville, Maryland.

\section{RESULTS}

All rodents, their collection localities, and the coccidians with which they were infected are presented in Table I.

\section{Cyclospora angimurinensis n. sp.}

(Figs. 1-3, 12)

\section{Description}

Oocyst subspheroidal with thin wall $(\sim 1)$ composed of 2 layers of equal thickness; outer layer smooth; micropyle absent; oocyst residuum as $3-4$ clumped globes of different sizes; 1 polar body present; sporulated oocysts $(\mathrm{n}=52) 21.9 \times 19.3(19-24 \times 16-22)$ with $\mathrm{L}: \mathrm{W}$ ratio $1.1+(1.1-1.3)$; sporocysts $(\mathrm{n}=51)$ lemonshaped, $11.9 \times 9.5(9-15 \times 8-11)$ with $\mathrm{L}: \mathrm{W}$ ratio 1.25 (1.1-1.5); Stieda body present, but sub- and parastieda bodies are absent; sporocyst residuum of small gran- 
TABle I. Coccidian parasites collected from pocket mice, Chaetodipus, Perognathus, and Liomys spp., and from kangaroo rats, Dipodomys elator, collected in the southwestern United States, Baja California, and northern Mexico.

\begin{tabular}{|c|c|c|c|}
\hline Rodents & Locality & $\begin{array}{l}\text { Mice infected/ } \\
\text { mice examined } \\
(\%)\end{array}$ & Coccidia spp. \\
\hline Chaetodipus arenarius & Baja California, Norte & $0 / 20$ & - \\
\hline Chaetodipus baileyi & Baja California, Norte & $0 / 16$ & - \\
\hline \multirow[t]{6}{*}{ Chaetodipus californicus } & Baja California, Norte & $17 / 28(61)$ & $\begin{array}{l}\text { Eimeria albigulae, Eimeria arizonensis, Eimeria reedi, Eimeria } \\
\text { scholtysecki, sp.* }\end{array}$ \\
\hline & Los Angeles Co., California & $0 / 1$ & - \\
\hline & Madera Co., California & $1 / 2(50)$ & E. reedi \\
\hline & Riverside Co., California & $5 / 13(38)$ & E. reedi, $E$. scholtysecki, sp.* \\
\hline & San Bernardino Co., California & $1 / 1(100)$ & E. reedi \\
\hline & San Diego Co., California & $1 / 1(100)$ & E. reedi \\
\hline Chaetodipus fallax & Baja California, Norte & $13 / 30(43)$ & E. reedi, sp.* \\
\hline Chaetodipus formosus & Baja California, Norte & $7 / 20(35)$ & E. reedi \\
\hline \multirow[t]{7}{*}{ Chaetodipus hispidus } & Hardeman Co., Texas & $3 / 5(60)$ & E. reedi \\
\hline & Hood Co., Texas & $4 / 4(100)$ & Eimeria chaetodipi, $E$. reedi \\
\hline & Jack Co., Texas & $1 / 1(100)$ & Eimeria hispidensis, $E$. reedi \\
\hline & Johnson Co., Texas & $2 / 3(67)$ & E. hispidensis, Eimeria langebarteli, $E$. reedi \\
\hline & Motley Co., Texas & $1 / 2(50)$ & E. reedi \\
\hline & Somervell Co., Texas & $2 / 2(100)$ & E. chaetodipi, E. hispidensis, Cyclospora angimurinensis, $E$. reedi \\
\hline & Wichita Co., Texas & $1 / 3(33)$ & E. reedi \\
\hline \multirow[t]{3}{*}{ Chaetodipus penicillatus } & Baja California, Norte & $0 / 11$ & - \\
\hline & Sonora & $3 / 13(23)$ & Eimeria merriami, $E$. reedi \\
\hline & San Bernardino Co., California & $1 / 1(100)$ & E. reedi \\
\hline Chaetodipus spinatus & Baja California, Norte & $5 / 7(71)$ & E. reedi, sp.* \\
\hline \multirow[t]{3}{*}{ Dipodomys elator } & Hardeman Co., Texas & $3 / 10(30)$ & E. arizonensis, Eimeria balphae \\
\hline & Wichita Co., Texas & $2 / 4(50)$ & E. arizonensis, E. balphae \\
\hline & Wilbarger Co., Texas & $3 / 7(43)$ & E. arizonensis, E. balphae \\
\hline Liomys pictus & Sonora & $2 / 3(67)$ & Eimeria liomysis \\
\hline Perognathus flavescens & Motley Co., Texas & $1 / 1(100)$ & sp.* \\
\hline \multirow[t]{6}{*}{ Perognathus flavus } & Hardeman Co., Texas & $1 / 1(100)$ & E. reedi \\
\hline & Hidalgo Co., New Mexico & $0 / 1$ & - \\
\hline & Hood Co., Texas & $1 / 1(100)$ & E. reedi \\
\hline & Somervell Co., Texas & $2 / 4(50)$ & $E$. reedi \\
\hline & Wichita Co., Texas & $0 / 1$ & - \\
\hline & Wilbarger Co., Texas & $1 / 3(33)$ & E. reedi \\
\hline Perognathus inornatus & Madera Co., California & $0 / 3$ & - \\
\hline \multicolumn{4}{|l|}{ Totals } \\
\hline \multicolumn{4}{|l|}{4 genera } \\
\hline 13 species & 17 localities & $84 / 223(38)$ & 11 spp. \\
\hline
\end{tabular}

* sp. = coccidia not identifiable because of unsporulated oocysts.

ules, either compact or dispersed; sporozoites with large posterior refractile body.

\section{Taxonomic summary}

Type host: Chaetodipus hispidus hispidus (Baird, 1858), hispid pocket mouse.

Type locality: U.S.A., Texas, Somervell County, 0.4 km NNE Nemo off county road 407.

Prevalence: Found in 1 of $20(4 \%) C$. h. hispidus collected from 7 counties in Texas.

Site of infection: Unknown, oocysts collected from feces.

Material deposited: Phototypes of oocysts in the USNMPC No. 80934. Host skin and skeleton in the ASUMZ, No. 18031 (adult male), C. T. McAllister \#158, 10 October 1987.

Etymology: The nomen triviale is derived from ang (Gr., vessel), muri (L., mouse), and -ensis (L., belonging to), indicating this parasite is from a pocket (vessel) mouse.

\section{Remarks}

Cyclosporans were described first from a myriapod, Glomeris sp., by Schneider (1881), but records from reptiles and mammals, especially insectivores (Pellérdy, 1974), are not uncommon. To date, there are 6 described mammalian cyclosporans, all from moles (see Duszynski and Wattam, 1988; Ford and Duszynski, 1988, 1989). The form we describe here differs from the other Cyclospora species by having an oocyst residuum and by the shape and $L: W$ ratio of its sporocysts (1.3 vs. 1.6 or larger).

\section{Eimeria chaetodipi n. sp.}

(Figs. 4-6, 13)

\section{Description}

Oocyst subspheroidal with thin wall $(<1)$ composed of only 1 obvious smooth layer; micropyle absent; oocyst residuum present as single small globe or absent; polar body present; sporulated oocysts $(n=43) 16.7$ 
$\times 14.6(13-19.5 \times 12-17)$ with $\mathrm{L}: \mathrm{W}$ ratio $1.1(1.0$ $1.3)$; sporocysts $(n=43)$ ovoidal, $8.7 \times 6.6(7.5-10.5$ $\times$ 5-7.5) with L:W ratio $1.3(1.1-1.6)$; Stieda body present, but sub- and parastieda bodies are absent; sporocyst residuum consists of a few small granules dispersed between sporozoites; sporozoites with a large, posterior refractile body.

\section{Taxonomic summary}

Type host: Chaetodipus hispidus hispidus (Baird, 1858), hispid pocket mouse.

Type locality: U.S.A., Texas, Hood County, 17.5 km SE Granbury off FM 2174 at Fort Spunky.

Other locality: U.S.A., Texas, Somervell County, $0.4 \mathrm{~km}$ NNE Nemo off County road 407.

Prevalence: Found in 3 of $20(15 \%) C$. h. hispidus collected from 7 counties in Texas.

Site of infection: Unknown, oocysts collected from feces.

Material deposited: Phototypes of oocysts in the USNMPC No. 80935. Host skin and skeleton in the ASUMZ, No. 17991 (adult male), C. T. McAllister \#97, 13 June 1987.

Etymology: The nomen triviale is derived from the generic name of the host.

\section{Remarks}

Although sporulated oocysts of this species resemble those of $E$. liomysis in shape, the small size distinguishes them from all eimerians described previously from heteromyid rodents.

\section{Eimeria hispidensis n. sp.} (Figs. 7-9, 14)

\section{Description}

Oocyst subspheroidal with wall $\sim 1$, composed of 2 layers: outer layer may be lightly sculptured, $\sim 2 / 3$ of total thickness; micropyle absent; oocyst residuum present as several globules of various sizes; 1 polar body present; sporulated oocysts $(n=49) 20.5 \times 17.4$ $(17-23 \times 14-21)$ with $\mathrm{L}: \mathrm{W}$ ratio $1.2(1.0-1.5)$; sporocysts $(n=49)$ lemon-shaped, $9.3 \times 7.2(7.5-10.5 \times$ 5-9), with L:W ratio 1.3 (1.1-1.5); Stieda body present, but sub- and parastieda bodies are absent; sporocyst residuum of several small globules; sporozoites with a large posterior refractile body.

\section{Taxonomic summary}

Type host: Chaetodipus hispidus hispidus (Baird, 1858), hispid pocket mouse

Type locality: U.S.A., Texas, Somervell County, 0.4 km NNE Nemo off county road 407.

Other localities: U.S.A., Texas, Jack County, 8.0 km SW Jacksboro, and Johnson County, 17 km SW Cleburne off county road 1120 at George's Creek Ranch.

Prevalence: Found in 4 of $20(20 \%) C$. h. hispidus collected from 7 counties in Texas. feces.

Site of infection: Unknown, oocysts collected from

Material deposited: Phototypes of oocysts in the USNMPC No. 80936. Host skin and skeleton in the ASUMZ, No. 18031 (adult male), C. T. McAllister \#158, 10 October 1987.

Etymology: The nomen triviale is derived from the specific part of the scientific name of the host and -ensis (L., belonging to) indicating that this form comes from $C$. $h$. hispidus.

\section{Remarks}

Sporulated oocysts of this form are most similar to those of $E$. liomysis, but differ by having an oocyst residuum that is never found in $E$. liomysis.

\section{Other eimerians}

Eimeria albigulae Levine, Ivens, and Kruidenier, 1957: Sporulated oocysts that were structurally identical to those of $E$. albigulae were found in 1 Chaetodipus californicus collected at Valle de la Trinidad, Baja California Norte, Mexico (MSB \#47481). This host was 1 of 28 C. californicus collected from several locations in Mexico; 17 of these mice were infected with various eimerians (Table I). This coccidian species was first described from Neotoma albigula, the white-throated woodrat (Muridae, see Anderson and Jones, 1984), from Arizona (Levine et al., 1957). This is the first report of $E$. albigulae in another genus.

Eimeria arizonensis Levine, Ivens, and Kruidenier, 1957: Sporulated oocysts that we could not distinguish from published descriptions of $E$. arizonensis were seen in 3 Dipodomys elator from 3 counties in Texas and in 1 C. californicus from Baja California Norte (Table I). This coccidian species was first described from Peromyscus truei in Arizona and later described from Peromyscus leucopus and Peromyscus maniculatus in Illinois (Levine and Ivens, 1960), P. maniculatus in British Columbia (Levine and Ivens, 1963), and in Peromyscus eremicus, $P$. maniculatus, and $P$. truei in New Mexico (Reduker et al., 1987). This is the first time that oocysts resembling those of $E$. arizonensis have been found outside members of the Muridae.

Eimeria balphae Ernst, Chobotar, and Anderson, 1967: This species was first described from a single Dipodomys ordii in Utah (Ernst, Chobotar, and Anderson, 1967) and it also has been reported from 15 of $137(11 \%)$ D. ordii from Texas (Short et al., 1980). This is the first report of $E$. balphae in $D$. elator, in which we found 8 of $21(38 \%)$ examined to be infected (Table I).

Eimeria langabarteli Ivens, Kruidenier, and Levine, 1959: This species, first described from Peromyscus boylii from Chihuahua, Mexico (Ivens et al., 1959), was later found in $P$. leucopus tornillo and in $P$. truei truei from New Mexico and California (Reduker et al., 1985). The sporulated oocysts we saw in 1 of $2 C . h$. hispidus from Texas were indistinguishable from those in the above descriptions. This is the first time this coccidian species has been found in a member outside the Muridae.

Eimeria liomysis Levine, Ivens, and Kruidenier, 1958: This species was reported from Liomys pictus in Sinaloa, Mexico, and from Liomys irroratus in Jalisco, Mexico (Levine et al., 1958), and from L. pictus in Nayarit and Sinaloa, Mexico (Ivens et al., 1959). We found it in 2 of $3(67 \%)$ L. pictus collected in Sonora, Mexico (Table I), which extends the parasite's range. Photomicrographs of sporulated oocysts of this species have not been published previously, but we include one here (Fig. 10).

Eimeria merriami Stout and Duszynski, 1983: This species was originally described from Dipodomys mer- 

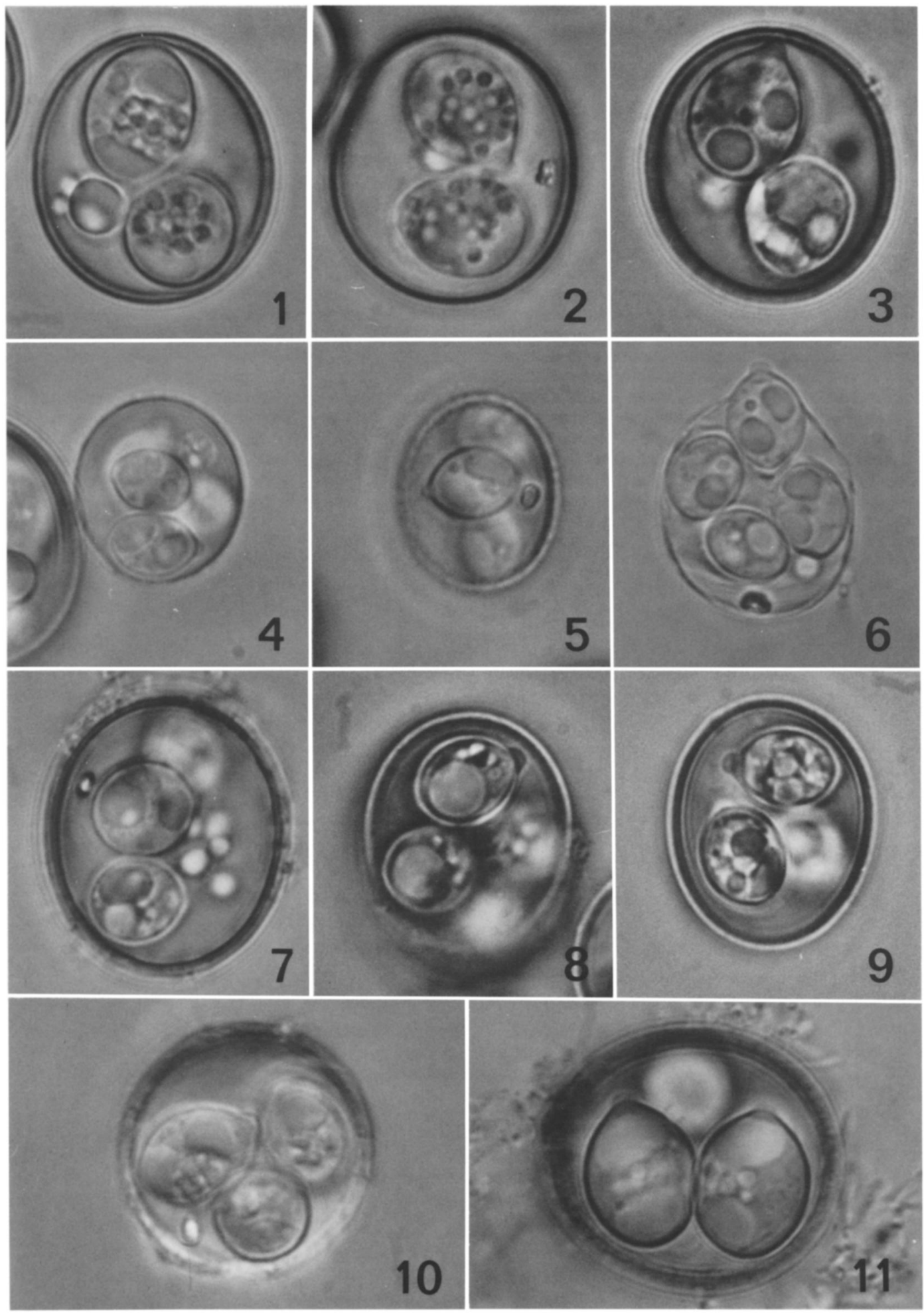

FIGURES 1-11. Photomicrographs of sporulated oocysts of coccidia collected from the feces of heteromyid rodents in the southwestern U.S. $\times 1,900.1-3$. Cyclospora angimurinensis $\mathrm{n} . \mathrm{sp}$. from Chaetodipus hispidus 

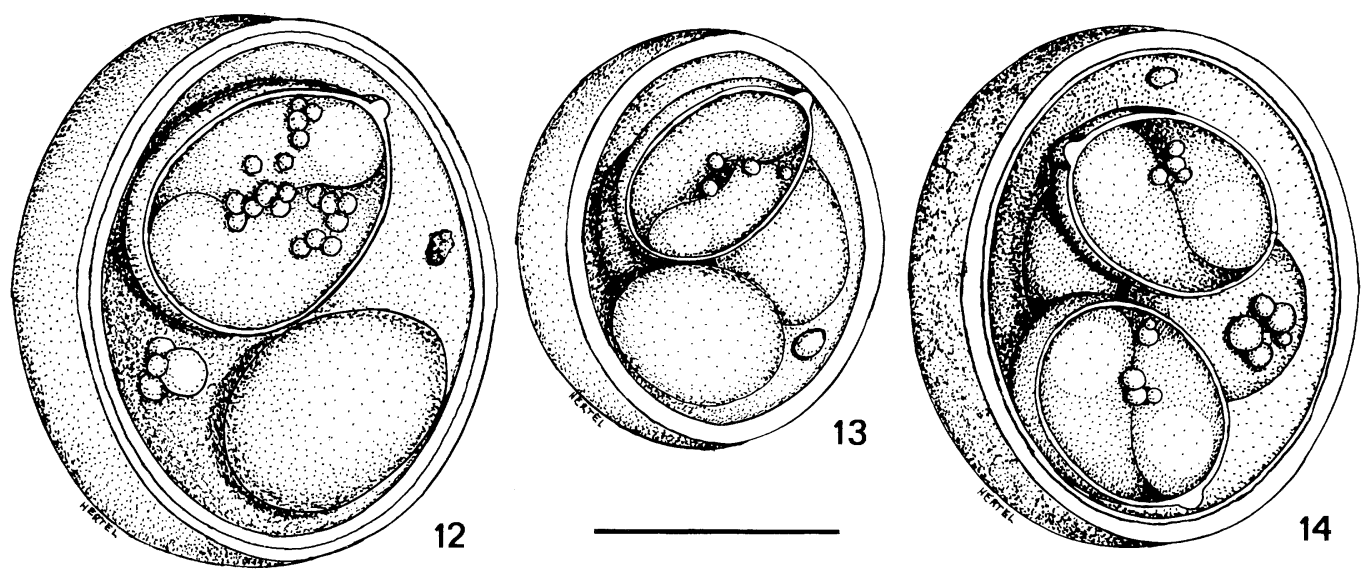

FIGURES 12-14. Line drawings of sporulated oocysts of coccidia collected from feces of Chaetodipus hispidus. Bar $=10 \mu \mathrm{m}$. 12. Cyclospora angimurinensis $\mathrm{n}$. sp. 13. Eimeria chaetodipi $\mathbf{n}$. sp. 14. Eimeria hispidensis $\mathrm{n} . \mathbf{s p}$.

riami from Baja California Norte (Stout and Duszynski, 1983). This is the first time it has been reported from Chaetodipus, in which we found it in 1 of $25(4 \%)$ Chaetodipus penicillatus from Mexico and the U.S.A.

Eimeria reedi Ernst, Oaks, and Sampson, 1970: The original description of $E$. reedi is from Chaetodipus formosus (=Perognathus formosus) from California (Ernst et al., 1970). We found it in 22 of $46(48 \%) C$. californicus from Mexico and California, 12 of 30 (40\%) Chaetodipus fallax from Mexico, 7 of 20 (35\%) C. formosus from Mexico, 5 of 20 (25\%) C. hispidus from Texas, 4 of $25(16 \%)$ C. penicillatus from Mexico and California, 3 of 7 (43\%) Chaetodipus spinatus from Mexico, and 5 of 11 (45\%) Perognathus flavus merriami from New Mexico and Texas (Table I). Photomicrographs of sporulated oocysts of this species have not been published previously, but we include one here (Fig. 11).

Eimeria scholtysecki Ernst, Frydendall, and Hammond, 1967: This species was originally described from D. ordii in Utah (Ernst, Frydendall, and Hammond, 1967). It has been reported also from Dipodomys agilis and Dipodomys gravipes from Baja California Norte and from Dipodomys spectabilis in New Mexico (Stout and Duszynski, 1983). We found it in the feces of 3 of 46 (6.5\%) C. californicus from California and Mexico
(Table I). This is the first record in members outside the genus Dipodomys.

\section{DISCUSSION}

Members of the family Heteromyidae (kangaroo rats, pocket mice, and their allies) constitute a morphologically and ecologically diverse collection of rodents that possesses adaptations that allow inhabitation of arid and semiarid regions of the southwestern United States and Mexico. These rodents nest in underground burrows that range from simple tunnels made by juveniles to intricate systems composed of 2 or more entrances constructed by adults (Blair, 1937). Often, no more than 1 individual inhabits a burrow system, and its feces are usually deposited in blind side tunnels. These 2 factors may limit exposure of certain taxa of heteromyid rodents to coccidian oocysts. However, the overall prevalence of infection $(84 / 223,38 \%)$ is moderate, and other factors (behavior, genetic, phys-

hispidus. Note oocyst residuum of clumped globules, polar body, lemon-shape of sporocysts with distinct Stieda body, and granular sporocyst residuum; also note there are only 2 sporozoites per sporocyst. 4-6. Eimeria chaetodipi $\mathrm{n}$. sp. from $C$. h. hispidus. Note small size of oocyst, polar body, and large posterior refractile body of sporozoites; what appears to be a substieda body in Figure 6 is a portion of the broken oocyst wall lying in the same focal plane as the sporocyst. 7-9. Eimeria hispidensis n. sp. from $C$. h. hispidus. Note polar body, globular sporocyst residuum, large posterior refractile body of sporozoites, and presence of Stieda body. 10. Eimeria liomysis Levine, Ivens, and Kruidenier, 1958, from Liomys pictus. This is the first published photomicrograph of an organism of this species. Note the absence of an oocyst residuum, the small Stieda body, and the highly refractile polar body that characterize this species. 11. Eimeria reedi Ernst, Oaks, and Sampson, 1970, from Chaetodipus californicus. This is the first published photomicrograph of an organism of this species. Note the Stieda and substieda bodies, large posterior refractile body of sporozoite, and large homogeneous oocyst residuum (below field of focus) that characterize this species. 
iologic) may account for Chaetodipus arenarius, Chaetodipus baileyi, Perognathus inornatus, and certain cohorts of Chaetodipus penicillatus to be negative for coccidia.

A higher prevalence of infection appears to be related to those taxa that avoid desert extremes by ranging farther into the plains and prairie regions of the midwestern United States where climatological conditions account for more humidity and precipitation. For example, when the rodents we examined are placed into 2 geographic groups, a western group of 9 species in 3 genera (C. arenarius, C. baileyi, C. californicus, C. fallax, C. formosus, $C$. penicillatus, $C$. spinatus, $P$. inornatus, L. pictus) and a midwestern group of 4 species in 3 genera (C. hispidus, D. elator, Perognathus flavescens, $P$. flavus), a significant difference in prevalence is evident (56/170 [33\%] vs. 28/53 [53\%], $\chi^{2}=7.3, P<0.007$ ).

Although some of the coccidians reported from heteromyid rodents may be host specific (e.g., the new species from $C$. hispidus), there is at least circumstantial evidence of less host specificity among others. For example, where P. flavus and C. hispidus coexist in Somervell County, Texas, they were not found to share the 3 new species described from the latter host. The reasons for such apparent host specificity in these coccidians of $C$. hispidus are obscure but may be related to the fact that this rodent is unique morphologically (Hafner and Hafner, 1983) and biochemically divergent (Patton et al., 1981) from all other congeners and from Perognathus spp. At the other extreme, some heteromyid eimerians seem to have a more cosmopolitan host range when we used the only measure available to us, namely, the structure of sporulated oocysts. For example, the combination of size, shape, and internal structures described by Ernst et al. (1970) make sporulated oocysts of Eimeria reedi a unique entity, and we found such oocysts in the fecal material of 7 species of Chaetodipus and Perognathus from California, New Mexico, Texas, and Mexico. In addition, the sporulated oocysts of several other species of coccidia originally reported from murid rodents by us and by others were seen to cross familial boundaries to heteromyid hosts, using the same criteria as above. Given that some internal structures, such as residua, may change in size and shape over time in stored, sporulated oocysts, we recognize that careful cross-transmission and life cycle studies are needed to examine this whole problem in much more detail.
Stout and Duszynski (1983) provided a summary of coccidia from kangaroo rats (Dipodomys spp.) in the western United States, Baja California, and northern Mexico. They reported that of 1,590 specimens representing 11 species of $D i$ podomys from various regions of North America and Mexico, only $13.4 \%$ were positive for coccidia and that prevalence of infection for any host ranged from 0 to $45 \%$, rarely exceeding $25 \%$. In the present study, 8 of 21 (38\%) D. elator from northern Texas harbored coccidia.

Finally, we have provided a description of a new species of Cyclospora from a host outside the mammalian order known to be infected commonly with members of this genus, namely, insectivores. Although a suitable host, the eastern mole (Scalopus aquaticus), is distributed throughout much of central and eastern Texas, including counties sampled by us, these moles are scarce or absent in stony and gravelly soils. The study site in Somervell County from which the type host of $C$. angimurinensis was collected does not support soil types inhabited by $S$. aquaticus (i.e., moist, sandy loam) and, most importantly, moles have not been trapped there, and we have never observed surface burrows there. Thus, we believe that $C$. angimurinensis does not represent a population of oocysts from a mole just passing through the intestinal tract of C. hispidus.

\section{ACKNOWLEDGMENTS}

We thank Dr. Steve J. Upton for technical assistance. C.T.M. thanks G. Roberts for allowing access to his properties and the Texas Parks and Wildlife Department for Scientific Collecting Permit SPO44-1. We are also indebted to Drs. J. H. Bandoli, T. L. Best, S. B. George, D. J. Hafner, L. L. Janacek, K. E. Peterson, D. W. Reduker, R. M. Sullivan, and T. L. Yates and to A. S. Christmas, J. A. Cook, D. A. Goebel, J. Haydock, and J. Planz for collecting many of the heteromyid rodents in our samples, to Mr. Todd Hill, Albuquerque TVI, for screening many of the samples and for his help in identifying some of the coccidians seen, and to Lynn A. Hertel for the line drawings.

\section{LITERATURE CITED}

ANDERSON, S., AND J. K. Jones, JR. (eds.). 1984. Orders and families of recent mammals of the world. John Wiley \& Sons, Inc., New York, p. 294-309.

Bandoni, S. M., AND D. W. DuszYNSKI. 1988. A plea for improved presentation of type material for coccidia. Journal of Parasitology 74: 519-523. 
BlaIR, W. F. 1937. The burrows and food of the prairie pocket mouse. Journal of Mammalogy 18: 188-191.

Duszynski, D. W., G. EAstham, and T. L. Yates. 1982. Eimeria from jumping mice (Zapus spp.): A new species and genetic and geographic features of Z. hudsonius luteus. Journal of Parasitology 68: 1146-1148.

, AND A. R. WATTAM. 1988. Coccidian parasites (Apicomplexa: Eimeriidae) from insectivores. IV. Four new species in Talpa europaea from England. Journal of Protozoology 35: 58-62.

Ernst, J. V., B. Chobotar, and L. C. ANDERson. 1967. Eimeria balphae n. sp. from the ord kangaroo rat Dipodomys ordii. Journal of Protozoology 14: 547-548.

-, M. J. Frydendall, AND D. M. HAMmond. 1967. Eimeria scholtysecki n. sp. from Ord's kangaroo rat Dipodomys ordii. Journal of Protozoology 14: $181-182$.

$\longrightarrow$, E. C. OAKS, AND J. R. SAMPSON. 1970. Eimeria reedi sp. n. and $E$. chobotari sp. n. (Protozoa: Eimeriidae) from heteromyid rodents. Journal of Protozoology 17: 453-455.

FORD, P. L., AND D. W. DUSZYNSKI. 1988. Coccidian parasites (Apicomplexa: Eimeriidae) from insectivores. VI. Six new species from the Eastern mole, Salopus aquaticus. Journal of Protozoology 35: 223-226.

- AND — 1989. Coccidian parasites (Apicomplexa: Eimeriidae) from insectivores. VII. Six new species from the hairy-tailed mole, Parascalops breweri. Journal of Parasitology 75: 508-513.

HAFNer, J. C., AND M. S. HAFNER. 1983. Evolutionary relationships of heteromyid rodents. Great $\mathrm{Ba}$ sin Naturalist Memoirs 7: 3-29.

IVENS, V., F. J. KRUIDENIER, AND N. D. Levine. 1959. Further studies of Eimeria (Protozoa: Eimeriidae) from Mexican rodents. Illinois Academy of Science Transactions 51: 53-57.

Levine, N. D., AND V. Ivens. 1960. Eimeria and Tyzzeria (Protozoa: Eimeriidae) from deermice
(Peromyscus spp.) in Illinois. Journal of Parasitology 46: 207-212.

- AND -. 1963. Eimeria siniffi sp. n. and E. arizonensis (Protozoa: Eimeriidae) from deermice in British Columbia. Journal of Parasitology 49: 660-661.

$\longrightarrow,-$ AND F. J. KRUIDENIER. 1957. New species of Eimeria from Arizona rodents. Journal of Protozoology 4: 80-88.

- - AND - 1958. New species of Eimeria (Protozoa: Eimeriidae) from Mexican rodents. Illinois Academy of Science Transactions 50: 291-298.

Patton, J. L., S. W. Sherwood, and S. Y. Yang. 1981. Biochemical systematics of chaetodipine pocket mice, genus Perognathus. Journal of Mammalogy 62: 477-492.

Pellérdy, L. P. 1974. Coccidia and coccidiosis, 2nd ed. Verlag Paul Parey, Berlin, 959 p.

Reduker, D. W., D. W. DuszYNSKI, AND T. L. YATES. 1987. Evolutionary relationships among Eimeria spp. (Apicomplexa) infecting cricetid rodents. Canadian Journal of Zoology 65: 722-735.

$\longrightarrow$, L HERTEL, AND D. W. DUSZYNSKI. 1985. $E i-$ meria species (Apicomplexa: Eimeriidae) infecting Peromyscus rodents in the southwestern United States and northern Mexico with description of a new species. Journal of Parasitology 71: 604-613.

SCHNEIDER, A. 1881. Sur les psorospermies oviformes ou coccidies. Especes nouvelles ou peu connues. Archives de Zoologie Expérimentale et Générale 9: 387-404.

Short, J. A., L. F. MAYberry, AND J. R. Bristol. 1980. Eimeria chihuahuaensis $\mathbf{s p}$. n. and other coccidia from Dipodomys spp. in El Paso County, Texas. Journal of Protozoology 27: 361-364.

Stout, C. A., AND D. W. DuszYNSKI. 1983. Coccidia from kangaroo rats (Dipodomys spp.) in the western United States, Baja California, and northern Mexico with descriptions of Eimeria merriami sp. n. and Isospora sp. Journal of Parasitology 69: 209-214. 